OPEN ACCESS

Edited and reviewed by:

Dominique J. Dubois,

Université Libre de Bruxelles, Belgium

*Correspondence:

Frontiers in Pharmacology Editorial Office

pharmacology.editorial.office

@frontiersin.org

Specialty section:

This article was submitted to

Pharmaceutical Medicine and

Outcomes Research,

a section of the journal

Frontiers in Pharmacology

Received: 25 February 2016

Accepted: 04 March 2016

Published: 08 April 2016

Citation:

Frontiers in Pharmacology Editorial Office (2016) Expression of Concern: Water hyacinth: a possible alternative rate retarding natural polymer used in

sustained release tablet design.

Front. Pharmacol. 7:62

doi: 10.3389/fphar.2016.00062

\section{Expression of Concern: Water hyacinth: a possible alternative rate retarding natural polymer used in sustained release tablet design}

\author{
Frontiers in Pharmacology Editorial Office *
}

An expression of concern on

Water hyacinth: a possible alternative rate retarding natural polymer used in sustained release tablet design

by Khatun, S., and Sutradhar, K. B. (2014). Front. Pharmacol. 5:137. doi: 10.3389/fphar.2014.00137

With this notice, we alert readers that Frontiers has received two messages questioning the soundness of the experimental results of the publication "Water hyacinth: a possible alternative rate retarding natural polymer used in sustained release tablet design" published on 11 June 2014 in Frontiers in Pharmacology. Our Chief Editors, Prof. Theophile Godfraind and Dr. Dominique Dubois, will direct an investigation in full accordance with our procedures and with the collaboration of the authors. The situation will be updated as soon as the investigation is complete.

Copyright $\odot 2016$ Frontiers in Pharmacology Editorial Office. This is an open-access article distributed under the terms of the Creative Commons Attribution License (CC BY). The use, distribution or reproduction in other forums is permitted, provided the original author(s) or licensor are credited and that the original publication in this journal is cited, in accordance with accepted academic practice. No use, distribution or reproduction is permitted which does not comply with these terms. 